\title{
CAUSES OF DEATH IN WILD MAMMALS RECEIVED AT CETAS / IBAMA IN RIO BRANCO, ACRE, BRAZIL: OBSERVATIONAL STUDY
}

1 Raimunda Beserra da Silva

1 Giovana Barbosa Morais

2 Luis Eduardo Maggi

3 Vanessa Lima de Souza

4 Yuri Karaccas de Carvalho

5 Vânia Maria França Ribeiro

5 Francisco Glauco de Araújo Santos raibeserras@gmail.com

gih.barbosa1@gmail.com

luis.maggi@gmail.com

limasouzavannessa@gmail.com

ykaracas@yahoo.com.br

vania.rib@uol.com.br

francisco.araujo@ufac.br
(D)

(1)

(1)

(iD

(1)

(1D)

1 Laboratório de Patologia e Clínica de Apoio à Vida Silvestre, Universidade Federal do Acre UFAC, Rio Branco, Acre, Brazil.

2 Centro de Ciências Biológicas e da Natureza - CCBN, Universidade Federal do Acre - UFAC, Rio Branco, Acre, Brazil.

3 Programa de Pós-Graduação em Sanidade e Produção Animal Sustentável na Amazônia Ocidental. Estr. Dias Martins, 2374-2544 - Campus da Universidade Federal do Acre, Rio Branco - AC. Brazil.

4 Laboratório de Tecnologia 3D. Estr. Dias Martins, 2374-2544 - Campus da Universidade Federal do Acre, Rio Branco - AC. Brazil.

5 Laboratório de Patologia e Clínica de Apoio à Vida Silvestre. Estr. Dias Martins, 2374-2544 Campus da Universidade Federal do Acre, Rio Branco - AC. 69920-905.

\section{ABSTRACT}

The necropsy of wild animals is necessary to raise the awareness of competent public organizations and the population about the risks of zoonosis. Given the scarcity of information this article aimed to survey the main injuries and causes of deaths of wild mammals kept in captivity was made, through the post mortem diagnosis and who passed through the Wild Animal Screening Center (Centro de Triagem de Animais Silvestres - CETAS) of Rio Branco - Acre, Brazil, from September 2012 to September 2015. After death, the animals were kept refrigerated or frozen until the time of necropsy, using the standard technique for small mammals. Fragments of organs and tissues were collected, and the material was processed for histopathology using formalin fixation (10.0\%), paraffin impregnation, hematoxylin, and eosin staining, in 4.0 $\mu \mathrm{m}$ thick sections. 42 animals were submitted to necropsy, 27 males (64.3\%) and 15 females $(35.7 \%)$, of which 21 were adults $(50.0 \%), 15$ were puppies $(35.7 \%)$ and six 
were young (14.3\%). The main cause of death was a hypovolemic shock $(11.6 \%)$, followed by starvation (9.3\%). There were also many deaths from undetermined causes (11.6\%). A greater occurrence of deaths was registered in the Guariba monkey (Alouatta senicullus). The identification of necropsy findings and the interpretation of macroscopic lesions showed that cardiovascular lesion was the most common death. There does not seem to be an influence between the dry and rainy periods on the number of deaths of these animals.

KEYWORDS: Post-mortem diagnosis, Necropsy, Wild Mammals, Brazilian Amazon. 


\section{INTRODUCTION}

Captive wild animals are continually exposed to immunosuppressive processes due to the intense and constant stress they are subjected to when they are captured. As a result, infections caused by opportunistic microorganisms can lead to death $(1,2)$.

The purpose of the Wild Animal Screening Center (Centro de Triagem de Animais Silvestres - CETAS) is to receive, identify, mark, screen, evaluate, recover, rehabilitate and dispose of wild animals (3). These are admitted in three different ways: 1) apprehension when they come from inspection actions of the Brazilian Institute for the Environment and Renewable Natural Resources (Instituto Brasileiro do Meio Ambiente e dos Recursos Naturais Renováveis - IBAMA) or the Environmental Police; 2) collection, when capture by IBAMA or the Environmental Police; 3) voluntary delivery when an illegal guardian voluntarily delivers the animal for any reason (4).

The high mortality observed in many cases of wild animals is directly related to habitat destruction, degradation, or fragmentation, as well as overexploitation, pollution, and the introduction of exotic species (2).

Necropsy is considered a method of great importance and relevance to determine pathologies in wild animals, collecting important information to be used in diagnosis, preventing and correcting errors, and assisting in treatments in future cases(5-7).

Despite its great importance, some studies demonstrate a decrease in animal necropsy requests in recent years, probably explained by advances in methods of approach (non-invasive) ante-mortem. However, these same studies draw attention due to the occurrence of discrepancies in clinical and anatomopathological findings, reinforcing the importance of necropsy in post-mortem diagnosis as a means of elucidating or confirming the cause of death $(8,9)$.

An anatomopathological diagnosis is a tool that helps clinicians and pathologists to relate the signs and symptoms observed before the individual's death with the anatomical findings (10). Thus, the objective of this study is to interpret the injuries and 
evaluate the causes of death in wild animals received at CETAS/IBAMA in Rio Branco, Acre.

\section{METHODS}

This is a clinical anatomopathological, cross-sectional study, based on a time series of reported cases of wild animals from CETAS/IBAMA in Rio Branco, Acre from September 2012 to September 2015.

The data of the animals like gender, species, physical condition were obtained from the forms filled out by CETAS while alive. The origin and provenance of the animals made it difficult to determine the actual age of each one, so the characterization of their age was performed using four categories: cub, young, adults, and elderly. The animals that died were made available to researchers frozen (under $0^{\circ} \mathrm{C}$ ) until the time of necropsy as an alternative to preserving the carcasses.

The technique used for systematic opening, inspection and detailing of cavities and organs was the standard for small animals. The animals were necropsied along this period and other data regarding the animals when in vivo were obtained from the records provided by this institution. After ectoscopy and internal visualization of the animals, samples were obtained through enucleations and incisions of the organs for further processing and microscopic analysis. The samples thus obtained were placed in containers with $10 \%$ formalin and sent to the Pathology and Wildlife Support Laboratory of the Federal University of Acre. So, they were submitted to routine histological techniques and stained with Hematoxylin and Eosin (HE).

Histological images were observed in a LEICA DM750 optical microscope (Leica ICC50 HD) and captured using the LAZ EZ software (Leica application suite 3.2.1). The identified and analyzed slides were filed. Diagnoses of causes of death were determined by post-mortem findings associated with lesions observed on histopathology.

This study was approved by CEUA - UFAC (Committee on Ethics in the Use of Animals, Federal University of Acre) under Number: 23107.005763/2014-68 and protocol number 02/2014. 


\section{RESULTS}

Overall, 42 wild mammals were necropsied of which 27 were males (64.3\%) and 15 females (35.7\%). The species with the highest number of deaths was Alouatta senicullus $(33,3 \%)$, followed by Leopardus pardalis $(7,1 \%)$ and Saguinus fuscicollis $(7,1 \%)$, respectively (Table 1$)$. About age, the statistics were: cub $(n=15 ; 35.7 \%)$, young $(n=6 ; 14.3 \%)$ and adults $(n=21 ; 50 \%)$, where $n$ is the number of individuals.

TABLE 1. List of wild mammals submitted to necropsy.

\begin{tabular}{lcccc}
\hline Scientific Name & M & F & Quant. & $\%$ \\
\hline Alouatta seniculus & 9 & 5 & 14 & $33.3 \%$ \\
Leopardus pardalis & 3 & 0 & 3 & $7.1 \%$ \\
Saguinus fuscicollis & 2 & 1 & 3 & $7.1 \%$ \\
Hydrochoerus hydrochaeris & 1 & 1 & 2 & $4.8 \%$ \\
Procyon cancrivorus & 0 & 2 & 2 & $4.8 \%$ \\
Lagothrix lagotrichia & 2 & 0 & 2 & $4.8 \%$ \\
Tamandua tetradactyla & 0 & 2 & 2 & $4.8 \%$ \\
Pithecia irrorata & 2 & 0 & 2 & $4.8 \%$ \\
Choloepus hoffmanni & 1 & 1 & 2 & $4.8 \%$ \\
Dasypus novemcinctus & 2 & 0 & 2 & $4.8 \%$ \\
Pecari tajacu & 1 & 0 & 1 & $2.4 \%$ \\
Callitrix pygmaea & 0 & 1 & 1 & $2.4 \%$ \\
Cebus albifrons & 1 & 0 & 1 & $2.4 \%$ \\
Saimiri boliviensis & 1 & 0 & 1 & $2.4 \%$ \\
Callimico goeldii & 1 & 0 & 1 & $2.4 \%$ \\
Dinomys branickii & 1 & 0 & 1 & $2.4 \%$ \\
Cavia aperea & 0 & 1 & 1 & $2.4 \%$ \\
Bradypus variegatus & 0 & 1 & 1 & $2.4 \%$ \\
\hline Total & $\mathbf{2 7}$ & $\mathbf{1 5}$ & $\mathbf{4 2}$ & $\mathbf{1 0 0 . 0} \%$ \\
\hline
\end{tabular}

M: male, F: female and Quant.: number of animals

The causes of death identified by necropsy were due to hypovolemic shock $(n=5 ; 11.6 \%)$ followed by starvation $(n=4 ; 9.3 \%)$, cardiorespiratory failure $(n=3 ; 7.0 \%)$, toxic shock $(n=3 ; 7.0 \%)$, hemodynamic shock $(n=3 ; 7.0 \%)$, trauma $(n=3 ; 7.0 \%)$ and 
malnutrition $(n=3 ; 7.0 \%)$, septic shock $(n=2 ; 4.7 \%)$, electrolyte disturbance $(n=2$; $4.7 \%)$, and respiratory failure $(n=2 ; 4.7 \%)$. It was not possible to determine the cause of death in $5(11.6 \%)$ animals. Other diagnoses involved various causes such as: electrocution ( $n=2 ; 4.7 \%)$, metabolic disorder, cardiac tamponade, heart failure, nervous causes, and cardiac arrest. Euthanasia was also performed (Table 2).

Table 2. Main findings that drought wild mammals to death

\begin{tabular}{l|c|c}
\hline FINDINGS & $\mathbf{n}$ & $\%$ \\
\hline Hypovolemic shock & 5 & $11.6 \%$ \\
\hline Undetermined causes & 5 & $11.6 \%$ \\
\hline Starvation & 4 & $9.3 \%$ \\
\hline Cardiorespiratory failure & 3 & $7.0 \%$ \\
\hline Toxic shock & 3 & $7.0 \%$ \\
\hline Hemodynamic shock & 3 & $7.0 \%$ \\
\hline Trauma & 3 & $7.0 \%$ \\
\hline Malnutrition & 3 & $7.0 \%$ \\
\hline Septic shock & 2 & $4.7 \%$ \\
\hline Electrolyte disturbance & 2 & $4.7 \%$ \\
\hline Respiratory failure & 2 & $4.7 \%$ \\
\hline Electrocution & 2 & $4.7 \%$ \\
\hline Metabolic disorder & 1 & $2.3 \%$ \\
\hline Cardiac tamponade & 1 & $2.3 \%$ \\
\hline Cardiac insufficiency & 1 & $2.3 \%$ \\
\hline Nervous cause & 1 & $2.3 \%$ \\
\hline Cardiac arrest & 1 & $2.3 \%$ \\
\hline Euthanasia & 1 & $2.3 \%$ \\
\hline TOTAL & $\mathbf{4 3}$ & $\mathbf{1 0 0 \%}$ \\
\hline
\end{tabular}

The most common necroscopic lesions were in the musculoskeletal, respiratory, and cardiovascular systems. $24.0 \%$ of the animals had some impairment of the cardiovascular system (Figure 1A and 1B) and $15.0 \%$ had a respiratory injury (Figure 
1C and 1D). $19.0 \%$ of animals submitted to necropsy contained fluid in the abdominal cavity, $11.9 \%$ in the thoracic cavity, and $4.8 \%$ in the pericardial sac. The main changes in organs and/or systems of animals undergoing necropsy are shown in Table 3.

Figure. 1. Necropsy and histopathological findings in wild mammals. (A) Alouatta senicullus bulged heart with enlarged ventricles $(\rightarrow)$. (B) Heart Micrograph of Alouatta senicullus showing the infarct center close to the endocardium $(\rightarrow)$ (10x objective). (C) Trachea and lungs of Pithecia irrorata with edema. (D) Lung micrograph of Pithecia irrorata showing severe alveolar edema $\left(^{\star}\right)(10 x$ objective) Hematoxylin-eosin.

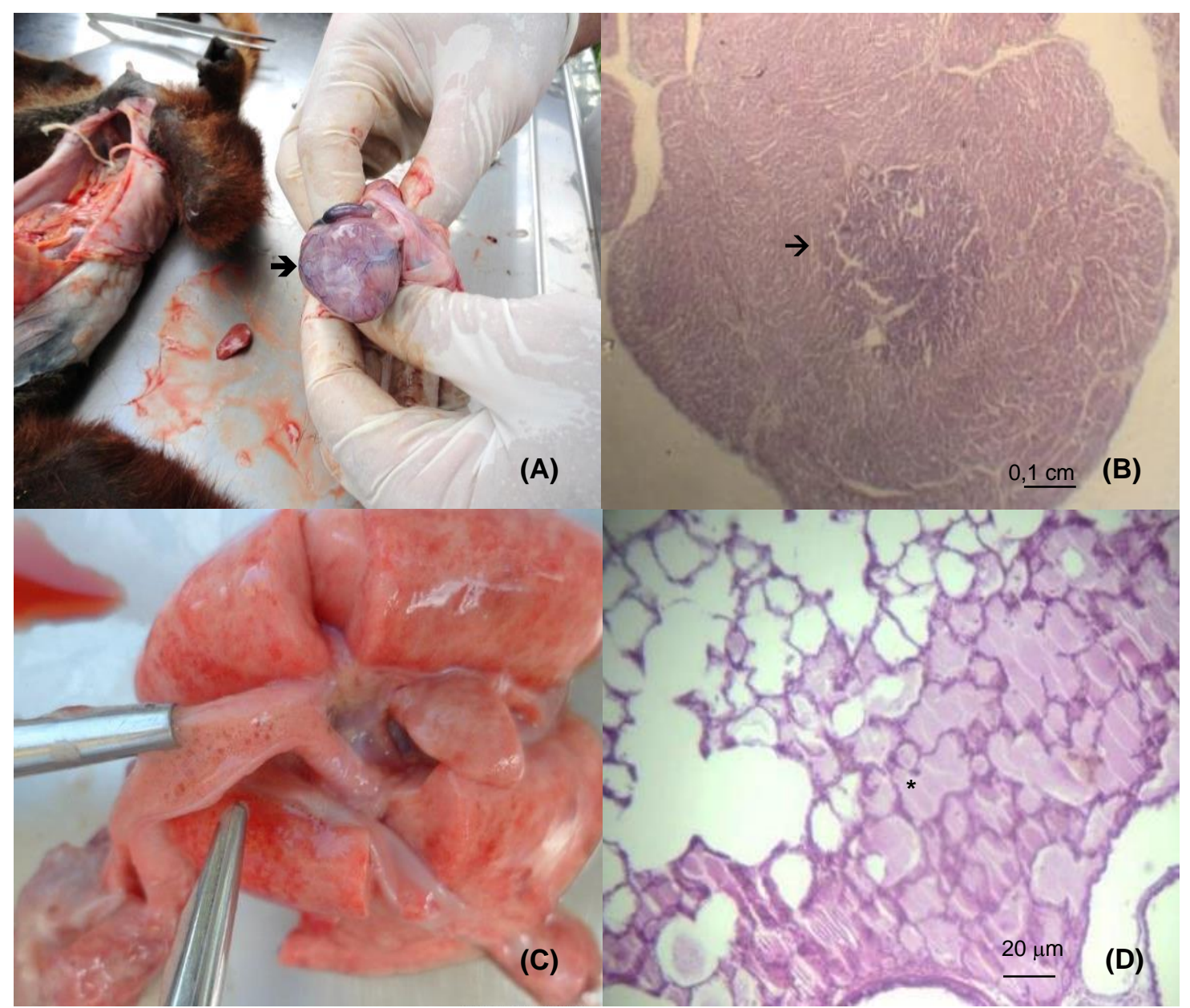

Mult. Sci. Rep. 2021; v.1 n. 2 / ISSN: 2764-0388 DOI: https://doi.org/10.54038/ms.v1i2.16 Submetido: 22 Novembro, 2021 - Aceito: 15 Dezembro, 2021 
Table 3. Main histopathological changes that led wild mammals to death.

\begin{tabular}{|c|c|c|c|c|}
\hline System & Findings & $\mathbf{n}$ & Total & $\%$ \\
\hline \multirow{5}{*}{ Cardiovascular } & Cardiac hypertrophy & 5 & \multirow{5}{*}{17} & \multirow{5}{*}{$24 \%$} \\
\hline & Mesenteric vascular congestion & 4 & & \\
\hline & Dilation of cardiac chambers & 4 & & \\
\hline & Clot in left ventricle & 2 & & \\
\hline & Coagulopathies & 2 & & \\
\hline \multirow{4}{*}{ Musculoskeletal } & Muscle pallor & 4 & \multirow{4}{*}{11} & \multirow{4}{*}{$15 \%$} \\
\hline & Bone mineral deficiency & 3 & & \\
\hline & Muscle Hypotrophy & 3 & & \\
\hline & Muscle hyperplasia & 1 & & \\
\hline \multirow{3}{*}{ Respiratory } & pulmonary edema & 6 & \multirow{3}{*}{11} & \multirow{3}{*}{$15 \%$} \\
\hline & Pneumonia & 3 & & \\
\hline & Atelectasis & 2 & & \\
\hline \multirow{4}{*}{ Digestive } & Enteritis & 4 & \multirow{4}{*}{8} & \multirow{4}{*}{$11 \%$} \\
\hline & Gastritis & 1 & & \\
\hline & Fecaloma & 1 & & \\
\hline & Liver with evident lobular pattern & 2 & & \\
\hline \multirow{2}{*}{ Lymphohematopoietic } & $\begin{array}{l}\text { Lymphadenomegaly } \quad \text { (mesenteric } \\
\text { lymphnodes) }\end{array}$ & 6 & \multirow[t]{2}{*}{11} & \multirow{2}{*}{$15 \%$} \\
\hline & Splenomegaly & 5 & & \\
\hline \multirow{3}{*}{ Urinary } & Full Bladder & 7 & \multirow{3}{*}{13} & \multirow{3}{*}{$18 \%$} \\
\hline & Renal congestion & 5 & & \\
\hline & Cystitis & 1 & & \\
\hline Total & & 71 & 71 & $100 \%$ \\
\hline
\end{tabular}

It was observed that an approximately equal number of deaths occurred both in the rainy season, which runs from November to May, and in the dry season, from June to October (11) (Figure 2). 
Fig. 2. Monthly distribution of deaths during the study period.

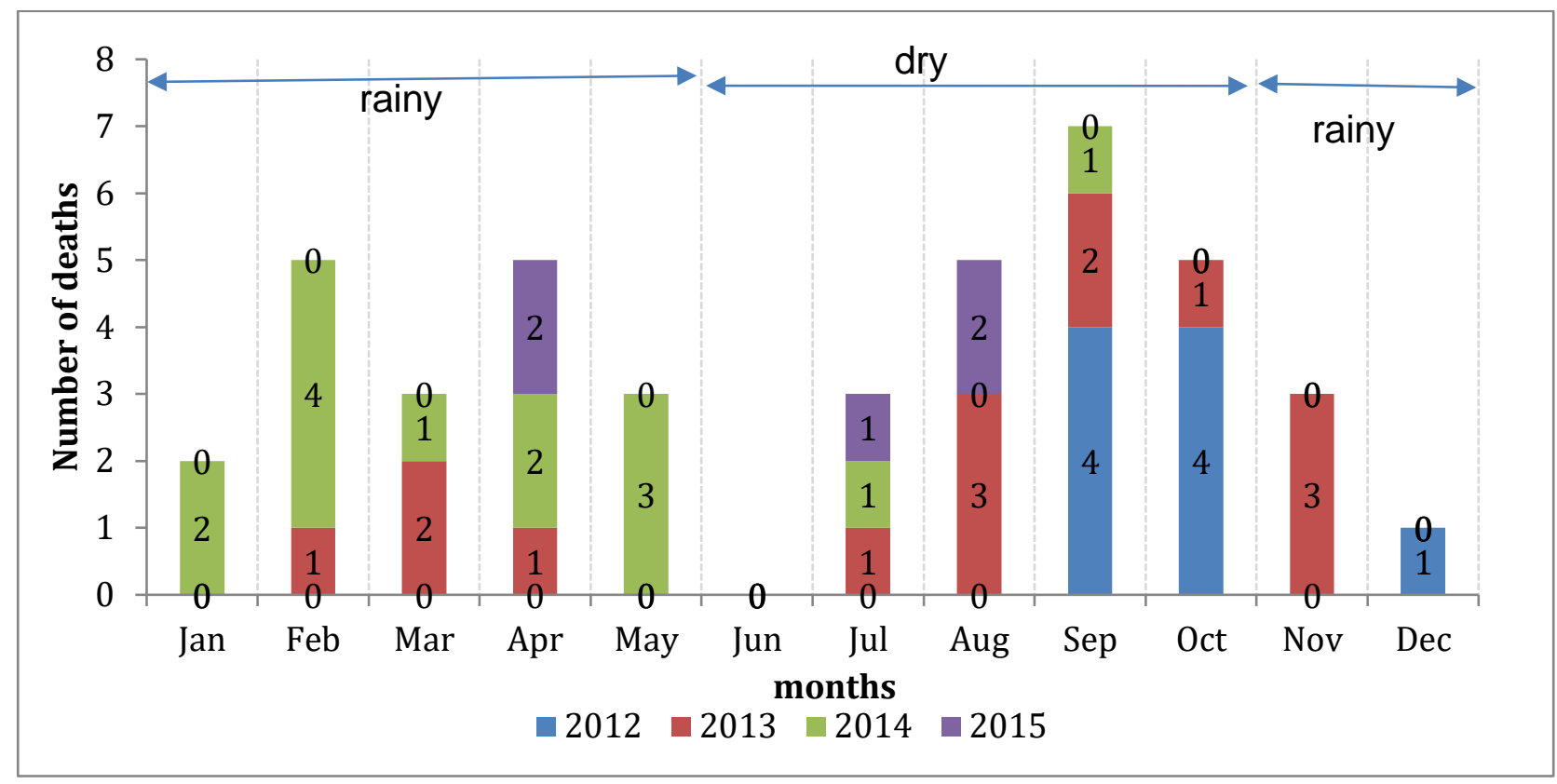

\section{DISCUSSIONS}

Similar data to those reported here about ages were found in PUERTO (2012) in which $50 \%$ of mammals were classified as adults at CETAS/IBAMA of Pequena Central Hidrelétrica Anhanguera/SP (1).

Some animals classified as cub has died because of starvation. According to COSTA et al. (2012), animals illegally kept in captivity receive inadequate diets daily (12). The shortage of nutrients has repercussions on cellular, metabolic and structural changes, resulting in cellular damage that compromise tissue and organ functions, leading to clinical conditions of nutritional affection(13).

The species with the highest number of deaths was Alouatta senicullus, followed by Leopardus pardalis and Saguinus fuscicollis, respectively. Neotropical felids and primates suffer from population decline due to habitat fragmentation, hunting persecution, and various other anthropogenic actions (14). Due to these factors, the animals seek refuge in other places trying to survive, which leads to their capture and maintenance in captivity, until later rescue. 
A Mambira (Tamandua tetradactyla) and a Two-Toed Sloth (Choloepus hoffmanni) died because of electric shock on high-voltage wires. These animals had physical injuries (mechanical traumatic burns) in the fore and hind limbs, and especially in the palm pads. In addition, the sloth presented a fracture in the left tarsus, with myiasis in the lesion. LIMA et al. (2012) reported a case of electrical trauma in a common sloth (Bradypus variegatus) and related the occurrence of electrical accidents in wild animals with the growth of the human population (15). Also in this study, the authors report the death of the animal due to sepsis, noting that in these cases burns are closely related to microbiological changes and in the nutritional and immune systems, which can interfere with the patient's recovery.

PUERTO (2012) classified the causes of death of wild mammals in the CETAS from Pequena Central Hidrelétrica Anhanguera/SP as non-infectious (54.29\%), indeterminate (25\%), and infectious (14.29\%) (1). Nutritional disorders stood out among the non-infectious causes.

The scarcity of information regarding necropsy findings in wild animals in the North region is due to the difficulty of working in this area due to its large territorial extension, the high cost of this type of research, the low population density, the difficult access in several areas and the absence of professionals able to carry out data collection (16).

In this study, five indeterminate cases were also observed due to the poor conservation conditions of the carcasses. The climatic conditions in the north region of Brazil (hot and humid equatorial climate) can contribute to the acceleration of the appearance of cadaveric alterations, making the necropsy report impossible. Other factors make it difficult to carry out the post-mortem diagnosis such as phenotypic characteristics of the animals like the small size of animals which decompose faster, external isolation by plenty of furs, nutritional status, type of diet, health status, added to the type of disease and the conditions of death (17).

Among the animals evaluated, 17 (41.46\%) had anemia and 14 (34.14\%) were malnourished. It was observed in the clinic analysis that they were apathetic and showed no interest in the food offered. Without eating and without replacing basic 
components of their diet, their health conditions only deteriorated further. And as such, the findings above explain what was observed in the clinic. Additionally, the fact that animals remain in CETAS for long periods can be considered. According to PUERTO (2012), the prolonged time that the animals are in CETAS, waiting for a license to be sent to other establishments, increases the possibility of death (1).

During the rainy season, climate change can increase the effects of respiratory diseases, impact on obtaining food, as well as alter the conditions of exposure to air pollutants (18). Possibly the high temperature, humidity, food supply, which are registered during the rainy season, could have contributed to the proliferation and spread of disease-causing agents, as well as weakened the organic condition of the animals, predisposing them to diseases. Even the smallest number of deaths having been registered in the "dry" season, it is worth mentioning that, in this period, animal deaths due to fires could also be registered (data not included, as animals arriving at CETAS/IBAMA, still are alive).

\section{CONCLUSIONS}

The identification of necropsy findings and the interpretation of macroscopic lesions showed that the highest number of deaths in wild animals received at CETAS/IBAMA in Rio Branco, Acre were the primates, including the howler monkey (Alouatta seniculus), that occur with high frequently. Among the histopathological lesions observed, cardiovascular ones were most correlated with the number of deaths in the species studied. There seems to be no influence between the dry and rainy periods in the number of deaths of these animals.

\section{ACKNOWLEDGEMENTS}

The authors specially thank the Brazilian Federal Agencies: "Coordenação de Aperfeiçoamento de Pessoal de Nível Superior" (CAPES), and the "Conselho Nacional de Desenvolvimento Científico e Tecnológico" (CNPq), Brazil. We would also like to thank the "Universidade Federal do Acre" and CETAS/IBAMA for all support. 


\section{DECLARATION OF CONFLICT OF INTEREST}

The authors declare no conflict of interest. The founding sponsors had no role in the design of the study; in the collection, analyses, or interpretation of data; in the writing of the manuscript, and in the decision to publish the results.

\section{AUTHORS' CONTRIBUTIONS}

All authors contributed equally to the conception and writing of the manuscript. All authors critically revised the manuscript and approved the final version.

\section{BIOETHICS AND BIOSECURITY COMMITTEE APPROVAL}

This study was approved by CEUA - UFAC (Committee on Ethics in the Use of Animals, Federal University of Acre) Protocol: 23107.005763/2014-68. 


\section{REFERENCES}

1. Puerto EAG. Causa de morte de animais silvestres oriundos de uma área de resgate: implicações na conservação [Internet]. Vol. 1. Universidade de São Paulo; 2012. Available from: http://bdtd.ibict.br/vufind/Record/USP_48663b8fe4bb50b7f3b968a91abc2539

2. Cubas ZS. Conservação e bem-estar animal. In: Roca, editor. Tratado de Animais Selvagens. 2nd ed. Sao Paulo, SP; 2014. p. 2512.

3. IBAMA. Sistema de gestão dos Centros de Triagem de Animais Silvestres do Ibama chega integrado à plataforma de Conversão de Multas Ambientais [Internet]. gov.br. 2019 [cited 2019 Jul 3]. Available from:

https://www.gov.br/ibama/pt-br/assuntos/notas/copy_of_notas/sistema-degestao-dos-centros-de-triagem-de-animais-silvestres-do-ibama-chegaintegrado-a-plataforma-de-conversao-de-multas-ambientais

4. Santos De Alexandria Pagano I, Barreto AE, De Sousa A, Guilherme P, Wagner C, Robson \&, et al. Aves depositadas no Centro de Triagem de Animais Silvestres do IBAMA na Paraíba: uma amostra do tráfico de aves silvestres no estado. Ornithologia. 2009;3(2):132-44.

5. Gonçalves GAM, Salgado BS. Necropsia cosmética em aves. Arch Vet Sci. 2011;16(2):9-17.

6. Batista JS, Olinda RG, Silva TMF, Rodrigues CMF, Oliveira AF, Queiroz SAC, et al. Enfermidades de cutias (Dasyprocta aguti) criadas em cativeiro diagnosticadas pelo exame anatomopatológico. Pesqui Vet Bras. 2010;30(6):497-502.

7. Peixoto PV, Barros CSL. A importância da necropsia em medicina veterinária. Pesqui Veterinária Bras. 1998;18(3-4):132-4.

8. Dank G, Segev G, Moshe D, Kent MS. Follow-up study comparing necropsy rates and discrepancies between clinical and pathologic diagnoses at a veterinary teaching hospital: 2009 versus 1989 and 1999. J Small Anim Pract. 
2012;53(12):679-83.

9. Kent MS, Lucroy MD, Dank G, Lehenbauer TW, Madewell BR. Concurrence between clinical and pathologic diagnoses in a veterinary medical teaching hospital: 623 Cases (1989 and 1999). J Am Vet Med Assoc. 2004;224(3):4036.

10. de Almeida MC, Couto LA, da Silva LH, Carvalhal S dos S. Correlação diagnóstica anatomoclínica. Aferição retrospectiva do diagnóstico clínico em necrópsias. Rev Saude Publica. 1989;23(4):285-91.

11. MINISTERIO DA AGRICULTURA PEA. INSTITUTO NACIONAL DE METEOROLOGIA [Internet]. GOVERNO FEDERAL. 2020 [cited 2020 Jul 3]. Available from: https://portal.inmet.gov.br/\#avisos

12. Costa R de CS da, Botteon R de CCM, Neves DM, Valladares MCM, Scherer PO. SAÚDE ORAL DE PRIMATAS DA ESPÉCIE Cebus apella (LINNAEUS, 1758) MANTIDOS NO CENTRO DE TRIAGEM DE ANIMAIS SILVESTRESIBAMA, ESTADO DO RIO DE JANEIRO. 86 Rev Bras Med Vet. 2012;34(2):86-90.

13. CARCIOFI AC, OLIVEIRA LD. Doenças Nutricionais. In: Roca, editor. Tratado de Animais Selvagens: Medicina Veterinária. Sao Paulo, SP; 2007. p. 838-64.

14. JORGE RSP, JORGE MLS. Carnívora - Felidae (Onça, Suçuarana, Jaguatirica e Gato-do-mato). In: Roca, editor. Tratado de Animais Selvagens: Medicina Veterinária. Sao Paulo, SP; 2007. p. 1202-14.

15. Lima DASD, Lima WC, Rodrigues MC, Quessada AM, Dos Santos KMM, De Moura CRC, et al. Trauma elétrico em preguiça de vida livre: relato de caso. Rev Port ciencias Vet [Internet]. 2012;111(583-584):199-202. Available from: http://www.fmv.ulisboa.pt/spcv/PDF/pdf12_2012.old/199-202.pdf

16. Boia MN, Motta LP da, Salazar M do SP, Mutis MPS, Coutinho RBA, Coura JR. Estudo das parasitoses intestinais e da infecção chagásica no Município de Novo Airão, Estado do Amazonas, Brasil. Cad Saude Publica. 
1999;15(3):497-504.

17. Caicedo J, Ospina J, Ávila J. Técnica de necropsia, interpretación de hallazgos macroscópicos y toma de muestras en mamíferos silvestres. Asocuación Vet y Vida Silv [Internet]. 2012;8(1):42-66. Available from:

https://www.researchgate.net/publication/320194988_Tecnica_de_Necropsia_I nterpretacion_de_Hallazgos_Macroscopicos_y_Toma_de_Muestras_en_Mami feros_Silvestres

18. Barcellos C, Monteiro AMV, Corvalán C, Gurgel HC, Carvalho MS, Artaxo P, et al. Mudanças climáticas e ambientais e as doenças infecciosas: cenários e incertezas para o Brasil. Epidemiol e Serviços Saúde. 2009;18(3):285-304. 